\title{
Comparative Analysis of Alternate Day and Daily Regimen of Atorvastatin in Dyslipidaemic South Indian Patients
}

\author{
Shanmugasundaram Rajamani, Maharani Balagurumoorthy \\ ${ }^{1}$ Associate Professor, Department of Medicine, Vinayaka Mission's Kirupananda Variyar (VMKV) Medical College \& Hospitals, \\ Salem, Tamilnadu, INDIA. \\ ${ }^{2}$ Associate Professor, Department of Pharmacology, Indira Gandhi Medical College \& Research Institute (IGMC \& RI), \\ Puducherry, INDIA.
}

\begin{abstract}
Background: Atorvastatin is the most commonly used drug for the treatment of dyslipidaemia. Long term administration of statins helps in the reduction of cardiovascular morbidity and mortality associated with dyslipidaemia. Number of studies have shown that alternate day dosing of statins is efficacious and safe alternative to daily dosing. Objectives: To compare the efficacy and tolerability of daily \& alternate day regimen of Atorvastatin in the treatment of naïve dyslipidaemic South Indian patients. Materials \& Methods: It is an open labeled, prospective, parallel, comparative interventional study. Ninety patients satisfying the inclusion criteria were randomized in to group 1 ( $n=45$ ) and group $2(n=45)$ and received atorvastatin $10 \mathrm{mg}$ daily and alternate days respectively for 3 months. Pretreatment and post treatment anthropometric measurements, biochemical and lipid parameters were recorded. Patients were followed at fortnightly intervals for 3 months to check the patient compliance and adherence to treatment. Data were analyzed by suitable statistical methods. Results: There was a statistically significant reduction of total cholesterol, triglycerides, LDL, VLDL and increase of HDL cholesterol in both groups. Post treatment between group comparison shows a significantly higher reduction of LDL in group 1 than group 2 patients. All other lipid parameters were significantly similar between the groups at 12 weeks follow-up. Daily and alternate day treatment were well tolerated by the patients of both the group and there was no untoward incident during the study period. Conclusion: Alternate day administration of atorvastatin causes a beneficial alternation of lipid parameters which helps in reducing the cost and adverse effects.
\end{abstract}

Key words: Alternate day, Atherosclerosis, Atorvastatin, Hyperlipidaemia, Adverse events.

Citation: Rajamani S, Balagurumoorthy M. Comparative Analysis of Alternate Day and Daily Regimen of Atorvastatin in Dyslipidaemic South Indian Patients. Int J Pharmacol and Clin Sci. 2016;5(4):97-102.

\section{INTRODUCTION}

Hyperlipidaemia is the major risk factor for atherosclerosis and atherosclerosis associated conditions like coronary heart disease, ischaemic cerebrovascular disease and peripheral vascular diseases. These conditions are associated with major morbidity and mortality in the middle and old age adults. ${ }^{[1]}$ Statins are the most commonly used drugs for the treatment of hyperlipidaemia. ${ }^{[2]}$ Atorvastatin is the most commonly used statin in the treatment of hyperlipidaemia. ${ }^{[3]}$ Literature review has demonstrated the beneficial effect of long term use of statins in the prevention of stroke and Coronary Heart Disease related morbidity and mortality associated with hyperlipidaemia. ${ }^{[4]}$
Statins are the competitive inhibitors of HMG-CoA reductase, the rate limiting enzyme in the cholesterol

Received : 8.7.2016 Revised : 7.11.2016;

Accepted : 21.12.2016

*Correspondence : Dr. B. Maharani,

Associate Professor, Department of Pharmacology, Indira Gandhi Medical College \& Research, Institute (IGMC \& RI), Puducherry, INDIA.

Phone no:09894344585

E-mail: drkarthikrani@gmail.com

Conflict of interest: Nil ; Source of support : Nil

Copyright: ${ }^{\odot} 2016$ Journal. All rights reserved.

DOI : 10.5530/ijpcs.5.4.1 
biosynthesis. ${ }^{[5]}$ Longer residence of drug or its metabolites in the liver and prolonged inhibition of HMG-Co. A reductase enzyme helps prescribing atorvastatin on alternate day basis also. ${ }^{[6]}$ Discontinuation rates of daily administration of atorvastatin are high because of adverse effects and expensiveness. ${ }^{[7,8]}$ Number of studies have shown alternate day dosing of statins is an efficacious and safe alternative to daily dosing of statins provided patients are not undertreated (patients on alternate day therapy should be able to reach the target lipid profile as per ATP III(Adult Treatment Panel), NCEP (National Cholesterol Education Program), guidelines). ${ }^{[9,10]}$ Till date, there are no such studies done on alternate day administration of statins in the treatment of hyperlipidaemia among South Indian Population. Hence the present study was planned to compare the efficacy and tolerability of daily and alternate day regimen of Atorvastatin in the treatment of naïve dyslipidaemic South Indian patients.

\section{MATERIALS AND METHODS}

\section{Study setting}

This is an open labeled, prospective, parallel, comparative interventional study. The study was conducted from January 2015 to February 2016 after obtaining Institutional Ethics Committee Clearance.

\section{Inclusion Criteria}

Male and female naïve patients aged between 30-70 yrs with only dyslipidaemia or associated co-morbid conditions like type-II diabetes, hypertension, low risk, moderate risk and moderately high risk dyslipidaemic patients as per ATP III guidelines and willing to follow the diet prescribed by dietician were included in the study.

\section{Exclusion Criteria}

Children, pregnant females, lactating mothers, liver disease, myopathy or muscle disorder patients, alcoholics, high risk and very high risk hyperlipidaemic patients (ATPIII, NCEP guidelines), H/o coronary artery diseases, stroke, unstable personalities, uncontrolled hypertensive and diabetics, undergone recent major surgery, concurrent use of other lipid lowering drugs and CYP 3A4 inhibitors or inducers and patients refusing to follow the diet prescribed by dietician were excluded from the study.

\section{Conduct of study and Drug regimen}

Totally 150 eligible patients were assessed, 90 patients satisfying the inclusion criteria were randomized in 1:1 manner in to group-1 or group-2 (45 in each group). Written informed consent was obtained from them. Group 1(n=45) was treated with atorvastatin $10 \mathrm{mg}$ daily and group $2(\mathrm{n}=45)$ was treated with atorvastatin $10 \mathrm{mg}$ on alternate days for 3 months. The patients were advised to take the medication after dinner. The patients were instructed to follow the standard diet prescribed by the dietician.

\section{Parameters and follow-up}

Anthropometric measurements (height, weight, BMI (Body Mass Index)) were recorded before and after the study period (3 months). Baseline investigations like Blood sugar, $\mathrm{Hb} \%$ (Haemoglobin), lipid profile, aspartate aminotransferase (AST) and alanine aminotransferase (ALT) level were recorded before and after the study period (3 months). The investigations were done after overnight fasting. Serum creatinine kinase level was recorded for the patients who complained of muscle weakness or discomfort during the study period. If the level was within the normal limits they were instructed to follow the medication. The patients were followed at fortnightly intervals to check for the compliance and adherence to the treatment by pill count at each visit. The patients were advised to report immediately in case of untoward events like muscle pain, weakness, nausea, abdominal pain, etc. No untoward incident occurred during the study period.

\section{Statistical analysis}

The data were analyzed with SPSS version 20. Descriptive statistics are explained with, frequency and percentage for categorical variables and mean $\pm \mathrm{SD}$ for continuous variables. Similarly the inferential statistics were carried out by using the Chi - square test for categorical variable and ' $\mathrm{t}$ ' test to test the significant difference in mean value for various parameters for both the groups, if any.

\section{RESULTS}

Among 90 patients included in the study, 32 patients in group 1 and 31 patients in group 2 completed the study. Out of 27 patients who did not complete the study, 10 patients were lost to follow-up, 5 patients were noncompliance to diet, 6 patients withdrew consent and 6 patients were non-compliance to treatment.

Baseline characteristics like age, gender, smoking habit, BMI, co-morbid conditions of group 1 and group 2 were 


\begin{tabular}{|c|c|c|c|c|}
\hline $\begin{array}{c}\text { Baseline } \\
\text { characteristics }\end{array}$ & $\begin{array}{c}\text { Group-1 } \\
(n=32)\end{array}$ & $\begin{array}{c}\text { Group-2 } \\
(n=31)\end{array}$ & $\begin{array}{l}\text { Chi- } \\
\text { square } \\
\text { test }\end{array}$ & P-Value \\
\hline $\begin{array}{c}\text { Age(in yrs) } \\
\text { Mean } \pm S . D, \\
\text { (range) }\end{array}$ & $\begin{array}{c}49.97 \pm 8.716 \\
(32-65)\end{array}$ & $\begin{array}{c}52.48 \pm 7.576 \\
(37-69)\end{array}$ & 6.059 & 0.109 * \\
\hline $\operatorname{Men}(n, \%)$ & $17(47.2)$ & $19(52.8)$ & 0.429 & $0.513^{*}$ \\
\hline Women $(\mathrm{n}, \%)$ & $15(55.6)$ & $12(44.4)$ & & \\
\hline $\begin{array}{l}\text { Smoking habit } \\
(\mathrm{n}, \%)\end{array}$ & $10(52.6)$ & $9(47.4)$ & 0.037 & $0.848^{*}$ \\
\hline $\begin{array}{c}\text { BMI } \\
\text { (Mean } \pm \text { S.D) }\end{array}$ & $\begin{array}{c}26.125 \\
\pm 4.7366\end{array}$ & $\begin{array}{c}26.226 \\
\pm 2.8485\end{array}$ & 3.702 & $0.157^{*}$ \\
\hline $\begin{array}{c}\text { Co-morbid } \\
\text { conditions (n, } \\
\%)\end{array}$ & $30(51.7)$ & $28(45.3)$ & 1.523 & $0.467^{*}$ \\
\hline
\end{tabular}

similar (Table 1). Baseline biochemical characteristics of both the groups were similar at the start of the study (Table 2).

There was a statistically significant reduction of total cholesterol $(\mathrm{P}<0.001)$, TGs $(\mathrm{P}<0.001)$, LDL $(\mathrm{P}<0.001)$, $\operatorname{VLDL}(\mathrm{P}<0.001)$ and significant increase of $\mathrm{HDL}$ cholesterol $(\mathrm{P}<0.001)$ among group 1 patients receiving Atorvastatin $10 \mathrm{mg}$ daily at the end of 12 weeks (Table 3). Similar results were also obtained in group 2 patients receiving Atorvastatin $10 \mathrm{mg}$ on alternate days at the end of 12 weeks (Table 3).

The changes in the lipid parameters between groups at the end of 12 weeks therapy were compared. There was a

\begin{tabular}{|c|c|c|c|c|c|c|}
\hline \multirow{2}{*}{$\begin{array}{c}\text { Lipid parameters } \\
\text { TC }\end{array}$} & \multirow{2}{*}{ Group } & \multirow{2}{*}{$\begin{array}{c}\text { Mean } \pm \text { S.D } \\
214.53 \pm 24.499\end{array}$} & \multirow{2}{*}{$\begin{array}{c}\text { Mean Difference } \\
-4.176\end{array}$} & \multicolumn{2}{|c|}{$95 \% \mathrm{Cl}$ of mean diff } & \multirow{2}{*}{$\frac{\text { Sig. (2-tailed) }}{0.440^{*}}$} \\
\hline & & & & -14.931 & 6.579 & \\
\hline & 2 & $210.35 \pm 17.494$ & & & & \\
\hline \multirow[t]{2}{*}{ TG } & 1 & $192.47 \pm 43.447$ & 5.628 & -16.065 & 27.321 & $0.606^{*}$ \\
\hline & 2 & $198.10 \pm 42.635$ & & & & \\
\hline \multirow[t]{2}{*}{ LDL } & 1 & $137.97 \pm 19.506$ & -3.969 & -12.158 & 4.221 & $0.336^{*}$ \\
\hline & 2 & $134.000 \pm 11.994$ & & & & \\
\hline \multirow[t]{2}{*}{$\mathrm{HDL}$} & 1 & $39.719 \pm 5.514$ & -2.719 & -6.423 & 0.9856 & $0.147^{*}$ \\
\hline & 2 & $37 \pm 8.858$ & & & & \\
\hline \multirow[t]{2}{*}{ VLDL } & 1 & $36.875 \pm 8.265$ & 2.706 & -1.539 & 6.951 & $0.207^{*}$ \\
\hline & 2 & $39.581 \pm 8.586$ & & & & \\
\hline
\end{tabular}

* - , P>0.01, Not significant (unpaired t-test)

\begin{tabular}{|c|c|c|c|c|c|c|c|c|c|c|}
\hline \multirow{2}{*}{$\begin{array}{c}\text { Lipid } \\
\text { Parameters }\end{array}$} & \multicolumn{3}{|c|}{ Group - 1 (Mean \pm S.D) } & \multicolumn{2}{|c|}{ Group-1 } & \multicolumn{3}{|c|}{ Group-2 (Mean \pm S.D) } & \multicolumn{2}{|c|}{ Group-2 } \\
\hline & Baseline & $\begin{array}{c}\text { After } \\
\text { 12weeks }\end{array}$ & $\begin{array}{c}\text { Mean } \\
\text { difference }\end{array}$ & SEM & $\begin{array}{c}\text { Sig. } \\
\text { (2-tailed) }\end{array}$ & Baseline & $\begin{array}{c}\text { After } \\
\text { 12weeks }\end{array}$ & $\begin{array}{c}\text { Mean } \\
\text { difference }\end{array}$ & SEM & $\begin{array}{c}\text { Sig. } \\
\text { (2-tailed) }\end{array}$ \\
\hline $\begin{array}{l}\text { Total cholesterol, } \\
\mathrm{mg} / \mathrm{dl}\end{array}$ & $\begin{array}{l}214.53 \pm \\
24.499\end{array}$ & $182.88 \pm 20.527$ & $\begin{array}{r}31.656 \\
\pm 13.258\end{array}$ & 2.344 & $0.000^{\star *}$ & $\begin{array}{r}210.35 \\
\pm 17.494\end{array}$ & $\begin{array}{c}189.81 \\
\pm 19.885\end{array}$ & $\begin{array}{c}20.548 \\
\pm 11.126\end{array}$ & 1.998 & $0.000^{* *}$ \\
\hline $\begin{array}{c}\text { Triglycerides, } \\
\text { mg/dl }\end{array}$ & $\begin{array}{c}192.47 \pm \\
43.447\end{array}$ & $173.91 \pm 41.588$ & $\begin{array}{c}18.563 \\
\pm 22.935\end{array}$ & 4.054 & $0.000^{\star *}$ & $\begin{array}{r}198.10 \\
\pm 42.635\end{array}$ & $\begin{array}{c}188.06 \\
\pm 41.138\end{array}$ & $\begin{array}{c}10.032 \\
\pm 13.925\end{array}$ & 2.501 & $0.000^{* *}$ \\
\hline $\mathrm{LDL}, \mathrm{mg} / \mathrm{dl}$ & $\begin{array}{c}137.97 \pm \\
19.506\end{array}$ & $107.16 \pm 15.598$ & $\begin{array}{c}30.813 \\
\pm 11.814\end{array}$ & 2.088 & $0.000^{* *}$ & $\begin{array}{c}134.00 \pm \\
11.994\end{array}$ & $\begin{array}{c}115.03 \\
\pm 14.577\end{array}$ & $\begin{array}{l}18.968 \\
\pm 8.746\end{array}$ & 1.571 & $0.000^{* *}$ \\
\hline $\mathrm{HDL}, \mathrm{mg} / \mathrm{dl}$ & $\begin{array}{c}39.719 \pm \\
5.514\end{array}$ & $41.47 \pm 5.599$ & $\begin{array}{c}-1.750 \pm \\
3.111\end{array}$ & 0.550 & $0.003^{\star *}$ & $37 \pm 8.858$ & $\begin{array}{l}37.94 \pm \\
8.520\end{array}$ & $\begin{array}{c}-0.935 \pm \\
1.692\end{array}$ & 0.304 & $0.004^{\star *}$ \\
\hline VLDL, mg/dl & $\begin{array}{c}36.875 \pm \\
8.265\end{array}$ & $34.38 \pm 8.579$ & $\begin{array}{c}2.500 \pm \\
3.672\end{array}$ & 0.649 & $0.001^{* *}$ & $\begin{array}{c}39.58 \pm \\
8.586\end{array}$ & $\begin{array}{l}37.61 \pm \\
8.429\end{array}$ & $\begin{array}{r}1.968 \\
\pm 3.371\end{array}$ & 0.606 & $0.003^{* *}$ \\
\hline
\end{tabular}

\footnotetext{
** $-\mathrm{P}<0.01-$ Significant (paired t-test)
} 


\begin{tabular}{|c|c|c|c|c|c|c|}
\hline \multirow{2}{*}{$\begin{array}{c}\text { Lipid parameters } \\
\text { TC2 }\end{array}$} & \multirow{2}{*}{ Group } & \multirow{2}{*}{$\begin{array}{c}\text { Mean } \pm \text { S.D } \\
182.88 \pm 20.527\end{array}$} & \multirow{2}{*}{$\begin{array}{c}\text { Mean Difference } \\
6.931\end{array}$} & \multicolumn{2}{|c|}{$95 \% \mathrm{Cl}$ of mean diff } & \multirow{2}{*}{$\begin{array}{c}\text { Sig. (2-tailed) } \\
0.178^{*}\end{array}$} \\
\hline & & & & -3.254 & 17.117 & \\
\hline & 2 & $189.81 \pm 19.885$ & & & & \\
\hline \multirow[t]{2}{*}{ TG2 } & 1 & $173.91 \pm 41.588$ & 14.158 & -6.687 & 35.004 & $0.179^{*}$ \\
\hline & 2 & $188.06 \pm 41.138$ & & & & \\
\hline \multirow[t]{2}{*}{ LDL2 } & 1 & $107.16 \pm 15.598$ & 7.876 & 0.264 & 15.487 & $0.042^{* *}$ \\
\hline & 2 & $115.03 \pm 14.577$ & & & & \\
\hline \multirow[t]{2}{*}{ HDL2 } & 1 & $41.469 \pm 5.599$ & -3.533 & -7.154 & 0.0877 & $0.055^{*}$ \\
\hline & 2 & $37.935 \pm 8.520$ & & & & \\
\hline \multirow[t]{2}{*}{ VLDL2 } & 1 & $34.375 \pm 8.579$ & 3.238 & -1.048 & 7.524 & $0.136^{*}$ \\
\hline & 2 & $37.613 \pm 8.429$ & & & & \\
\hline
\end{tabular}

**- $\mathrm{P}<0.05$, significant, *- $\mathrm{P}>0.05$, not significant (unpaired t-test)

\begin{tabular}{ccc}
$\begin{array}{c}\text { Table 5: Adverse events } \\
\text { Nature of adverse event }\end{array}$ & Group-1 & Group-2 \\
\hline Headache & 1 & 1 \\
Myalgia & 2 & 1 \\
Abdominal symptoms & 1 & 0 \\
Dizziness & 0 & 1 \\
Parasthesia & 0 & 0 \\
Elevated liver enzymes & 2 & 0
\end{tabular}

statistically significant higher reduction of LDL cholesterol in group 1 than group 2 (Table 4). All other lipid parameters were statistically similar between the groups at 12 week follow-up ( $\mathrm{P}>0.05$ for all). In other words, Atorvastatin 10 mg given daily and on alternate days had produced a similar pattern of increase of HDL cholesterol and reduction of total cholesterol, VLDL and triglycerides except greater reduction of LDL among group 1 patients. Biochemical parameters like blood sugar, $\mathrm{Hb} \%$ and liver enzymes were unaffected in both the groups at the end of follow-up except there was a minimal elevation of liver enzymes in two patients of group-1 (SGOT - 62, 74 IU/L, SGPT 68, $77 \mathrm{IU} / \mathrm{L}$ respectively) and they were clinically normal and asymptomatic. During the course of treatment two patients in group-1 and one patient in group - 2 reported muscle discomfort and Serum creatinine kinase levels were measured and it was within the normal limits (130150IU/L) (Table 5). Daily and alternate day treatment was well tolerated by the patients of both the group and there was no untoward incident during the study period.

\section{DISCUSSION}

In this study, the efficacy and tolerability of daily \& alternate day regimen of Atorvastatin were compared in

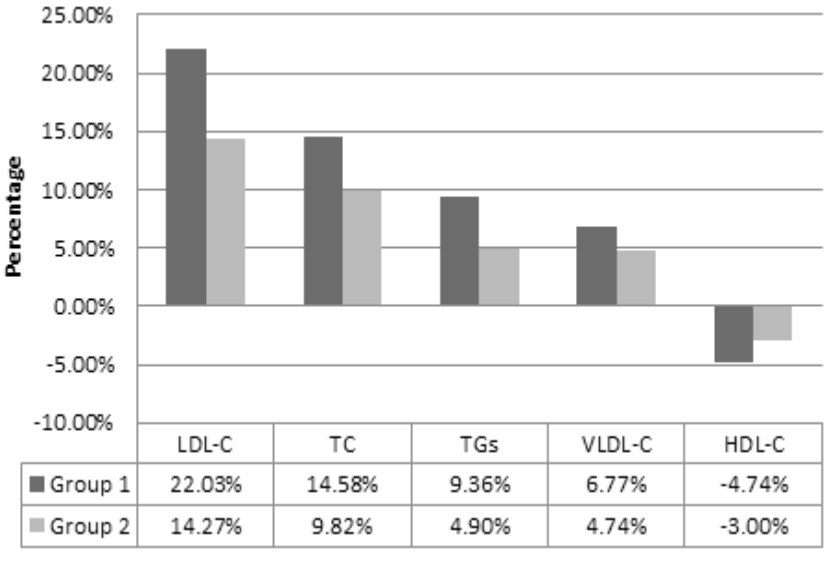

Figure 1: Mean percentage change of lipid parameters from baseline to post treatment

the treatment of dyslipidaemia among naïve South Indian patients. The results shows both daily and alternate day regimen of atorvastatin caused a statistically significant reduction of LDL, total cholesterol, triglycerides, VLDL and increase of HDL. Between groups comparison at the end of 12 weeks treatment showed significant higher reduction of LDL cholesterol in group-1 (22.03\%) than group- $2(14.27 \%$ ) patients (Figure 1). Reduction of total cholesterol, VLDL, TGs and elevation of HDL are higher in group 1 than group 2 but they are not significant. Noninferiority of alternate day regimen to daily regimen in terms of reduction of total cholesterol, VLDL, triglycerides and increase of HDL cholesterol was observed in the study, but reduction of LDL cholesterol in alternate day regimen was inferior to daily regimen. Though alternate day administration of atorvastatin was inferior to daily administration of atorvastatin, it had caused $14.27 \%$ of reduction of LDL cholesterol that was statistically significant. Alternate day dosing of atorvastatin was well tolerated with very few adverse effects. 
Results similar to the present study was observed in a study done by Rifaie $\mathrm{O} e t a l^{[11]}$ In contrast to the present study, other studies had shown statistically significant reduction of LDL cholesterol and total cholesterol with alternate day dosing of atorvastatin. ${ }^{[9,12-14]}$ Results published by Canna Jagdish Ghia et al., had shown alternate day dosing of atorvastatin was inferior to daily dosing of atorvastatin. ${ }^{[6]}$ It is a well known fact that reduction of serum cholesterol in response to statin therapy is highly variable. ${ }^{[1]}$ This may be the reason for varied responses in each published data. Further patient compliance in alternate day therapy has to be monitored properly as there are chances of missing of few doses.

In addition to the reduction of LDL and total cholesterol, statins have a potent anti-inflammatory activity which was observed even before the cholesterol lowering effect. ${ }^{[15]}$ In addition to reduction of hs-CRP, statins plays an important role in reduction and prevention of coronary events by its anti-atherosclerotic activity. ${ }^{[16]}$ Active metabolite generated by biotransformation of atorvastatin produces long lasting inhibition of HMG-CoA reductase enzyme (20-30h) which prolongs the duration of action of drug. ${ }^{[17,18]}$ Stern $\mathrm{RH}$ et al, had reported that serum total cholestrol and LDL-C increases after $72 \mathrm{~h}$ of atorvastatin discontinuation ${ }^{[19]}$ Further with alternate day administration of atorvastatin, cost can be cut-off by $50 \%$ and adverse effects can also be combated. ${ }^{[14,20]}$ All these properties adds the advantage of administrating atorvastatin on alternate day for primary prevention of dyslipidaemia associated morbidity and mortality. Further alternate day regimen will be advantageous to the patients who have experienced adverse effects to daily administration of atorvastatin.

\section{Study limitations}

This study is a single centre study with a small sample size which makes it difficult to generalize the data. Multicentre study involving large numbers of patient are needed before drawing solid conclusions. Other confounding factors are high variability in response to statin therapy, patient compliance, short follow-up period and lack of data on clinical end-points.

\section{CONCLUSION}

The current study demonstrated alternate day administration of atorvastatin is equally efficacious to daily administration of atorvastatin in terms of reduction of total cholesterol, VLDL, TGs and elevation of HDL. LDL cholesterol reduction with alternate day dosing was also significant when compared to baseline parameters. In conclusion, alternate day administration of atorvastatin causes a beneficial alternation of lipid parameters which helps in reducing the cost and adverse effects.

\section{ACKNOWLEDGEMENT}

The authors would like to acknowledge Medicine Department staff of VMKV Medical College \& Hospitals for their support in the conduct of the study.

The authors would also like to thank Dr. Vijay K. Chawada, Associate Professor, Community medicine, IGMC \& RI for his help in statistical work.

\section{CONFLICT OF INTEREST}

The authors declare they have no conflict of interest.

\section{REFERENCES}

1. Nelson RH. Hyperlipidemia as a Risk Factor for Cardiovascular Disease. Prim Care. 2013;40(1):195-211.

2. Corsini A, Bellosta S, Beatta R, Fumagalli R, Paoletti R, Bernini $F$. New insight into the pharmacodynamic and pharmacokinetic properties of statin. Pharmacol Ther. 1999;84(3):413-28.

3. Genest J, McPherson R, Frohlich J, Anderson T, Campbell N, Carpentier A, et al. 2009 Canadian Cardiovascular Society/ Canadian guidelines for the diagnosis and treatment of dyslipidemia and prevention of cardiovascular disease in the adult - 2009 recommendations. Can J Cardiol. 2009;25(10):567-579.

4. Law MR, Wald NJ, Rudnicka AR. Quantifying effect of statins on low density lipoprotein cholesterol, ischaemic heart disease, and stroke: systematic review and meta-analysis. BMJ. 2003;326(7404):1423.

5. Istvan ES, Deisenhofer J. Structural mechanism for statin inhibition of HMG-CoA reductase. Science. 2001;292(5519):1160-4.

6. Canna JG, Archana SP, Linesh RK, Rajesh KJ, Gautam $\mathrm{SR}$. Alternate day versus once daily Atorvastatin for primary preventionof $\mathrm{CHD}$ in naïve patients of dyslipidaemia. JCDR. 2014;8(3):27-31.

7. Thompson PD, Clarkson $\mathrm{P}, \mathrm{Karas} \mathrm{RH}$. Statin-associated myopathy. JAMA. 2003;289(13):1681-90.

8. Doshi JA, Zhu J, Lee BY, Kimmel SE, Volpp KG. Impact of a prescription copayment increase on lipid-lowering medication adherence in veterans. Circulation. 2009;119:390-7.

9. Ferrer-Garcia JC, Perez-silvestre J, Martinez-Mir I, HerreraBallester A. Alternate-day dosing of atorvastatin: effects in treating type 2 diabetic patients with Dyslipidaemia. Acta Diabetol. 2006;43(3):75-8

10. Matalka MS, Ravnan MC, Deedwania MD. Is alternate daily dose of atorvastatin effective in treating patients with hyperlipidaemia? The Alternate Day versus Daily Dosing of Atorvastatin Study (ADDAS). Am Heart J. 2002;144(4):674-7.

11. Osama Rifaie, Ahmed Zahran, Wail Nammas. Alternate versus daily atorvastatin in CAD. Anadolu Kardiyol Derg. 2012;12(2):90-6

12. Jafari $M$, Ebrahimi R, Ahmadi-Kashani M, Balian H, Bashir M. Efficacy of alternate day dosing versus daily dosing of atorvastatin. J Cardiovasc Pharmacol Ther. 2003;8(2):123-6. 
13. Piamsomboon C, Laothavorn $P$, Saguonwong $S$, CHatloong $B$, Nasawadi C, Tanprasert P. Efficacy and safety of atorvastatin 10 mg every other day in hypercholesterolemia. J Med Assoc Thai. 2002;85(3):297-300.

14. Juszezyk MA, Seip RL, Thompson PD. Decreasing LDL cholesterol and medication cost with every-other-day statin therapy. Prev Cardiol. 2005;8(4):197-9.

15. Ridker PM, Rifai N, Pfeffer M, Sacks F, Braunwald E. For the cholesterol and recurrent events (CARE) investigators. Long term effects of pravastatin on plasma concentration of plasma concentration of C-reactive protein. Circulation. 1999;100(3):230-5.

16. Ozaki K, Kubo T, Imaki R, Shinagawa H, Fukaya H, Ohtaki K, et al. The anti-atherosclerotic effects of lipid lowering with atorvastatin in patients with hypercholesterolemia. J Atheroscl Thromb.
2006;13(4):216-9.

17. Lea AP, Mc Tavisch D. Atorvastatin: a review of its pharmacology and therapeutic potential in the management of hyperlipidaemias. Drugs. 1997;53(5):828-47.

18. Jones PH. Comparing HMG-CoA reductase inhibitors. Clin Cardiol. 2003;26(suppl1):115-20.

19. Stern RH, Yang BB, Hounslow NJ, MacMahon M, Abel RB, Olson SC. Pharmacodynamics and pharmacokinetic relationships of atorvastatin, an HMG-CoA reductase inhibitor. J Clin Pharmacol. 2000;40(6):616-23.

20. Juszczyk MA, Seip RL, Thompson PD. Decreasing LDL cholesterol and medication cost with every-other-day statin therapy. Prev Cardiol. 2005;8():197-9. 